\title{
Publisher Correction: Frequent new particle formation over the high Arctic pack ice by enhanced iodine emissions
}

Andrea Baccarini (D), Linn Karlsson, Josef Dommen (1), Patrick Duplessis, Jutta Vüllers, lan M. Brooks, Alfonso Saiz-Lopez (D), Matthew Salter (1), Michael Tjernström (D), Urs Baltensperger, Paul Zieger (D) \& Julia Schmale (i)

Correction to: Nature Communications https://doi.org/10.1038/s41467-020-18551-0, published online 1 October 2020.

The manuscript contains two instances in which chemical compounds are incorrectly presented. These are $\mathrm{HSO}_{4-}$ in Fig. $1 \mathrm{~b}$, which should read $\mathrm{HSO}_{4}^{-}$, and $\mathrm{HOIO} 2$ in ref. ${ }^{85}$, which should be $\mathrm{HOIO}_{2}$.

Furthermore, there should not be a hyphen between 30 and nm on page 6 , line 2. In addition, there is inconsistent text alignment in the "Instrumentation and measurements" section in which full justified and left aligned text are mixed.

This has now been corrected in both the PDF and HTML versions of the Article.

Published online: 28 October 2020

\footnotetext{
(c) (i) Open Access This article is licensed under a Creative Commons Attribution 4.0 International License, which permits use, sharing, adaptation, distribution and reproduction in any medium or format, as long as you give appropriate credit to the original author(s) and the source, provide a link to the Creative Commons license, and indicate if changes were made. The images or other third party material in this article are included in the article's Creative Commons license, unless indicated otherwise in a credit line to the material. If material is not included in the article's Creative Commons license and your intended use is not permitted by statutory regulation or exceeds the permitted use, you will need to obtain permission directly from the copyright holder. To view a copy of this license, visit http://creativecommons.org/licenses/by/4.0/.
}

(C) The Author(s) 2020 